\title{
Nonlinear nexus between corruption and tourism arrivals: a global analysis
}

\author{
Krambia-Kapardis Maria ${ }^{1} \cdot$ Stylianou Ioanna ${ }^{2} \cdot$ Demetriou Salomi $^{2}$
}

Received: 22 July 2020 / Accepted: 12 December 2021 / Published online: 7 February 2022

(c) The Author(s) 2022

\begin{abstract}
The relationship between corruption and tourism has been sporadically examined over the years. According to the existing theory, there is an inverted U relationship which implies that tourism demand initially increases as corruption increases (greasing the wheels) and after a certain threshold level of corruption, tourism demand decreases (sanding the wheels). Empirical studies so far concentrated on capturing the nonlinear relationship, by applying a simple linear model and by including corruption as a quadratic term. In the current paper, the authors revisit the "greasing and sanding the wheels" hypothesis by applying an advanced econometric technique, the threshold regression model, which deals with a key element of model uncertainty, namely parameter heterogeneity. In particular, using a sample of 83 countries from 2001 to 2018 , the authors firstly examine if there is a nonlinear relationship between corruption and tourism, and then, they estimate the threshold value of corruption. According to the results, the null hypothesis of a linear model against the alternative of a threshold model with two regimes is strongly rejected. Furthermore, while the effect of corruption on tourism is positive in the low corruption regime and negative in the high corruption regime, a heterogeneous relationship is also found between other politicosocio-economic variables and tourism demand in the low and high corruption regimes.
\end{abstract}

Keywords Nonlinearities · Threshold regression · Corruption · Tourism demand

JEL Classification C59 $\cdot$ D73 $\cdot$ Z32 $\cdot$ L83

Stylianou Ioanna

istylianou@uclan.ac.uk

Krambia-Kapardis Maria

Maria.kapardis@cut.ac.cy

Demetriou Salomi

sdimitriou@uclan.ac.uk

1 Cyprus University of Technology, Limassol, Cyprus

2 University of Central Lancashire, Pyla, Cyprus 


\section{Introduction}

The growth in tourism since the 1950s is a global phenomenon and so is the concern about corruption. Regarding tourism growth, international tourist arrivals increased from 25 million in 1950 to 1.4 billion in 2018 (WTO 2018, 2019). In fact, the United Nation World Tourism Organization (UNWTO)'s Tourism Highlights noted in 2018 that international tourism arrivals in 2017 experienced the highest growth of $7 \%$ since 2010, contributing 10.4\% of global GDP. Also, growth in international tourist arrivals continued to outpace the economy in January 2020 before the COVID-19 pandemic that had first affected China and subsequently spread across the globe becoming a devastating pandemic. According to the UNTWO's Barometer on 18 January 2020 for all regions, international tourist arrivals (overnight visitors) worldwide grew $4 \%$ in 2019 to reach 1.5 billion.

The unprecedented COVID-19 pandemic at the time of writing (June 2020) makes accurate growth predictions impossible. Suffice it here to say that, according to UNWTO (2020a, b)'s "Impact assessment of the COVID-19 outbreak on international tourism" on 27 March 2020, "Current scenarios point to declines of 58-78\% in international tourist arrivals for the year, depending on the speed of the containment and the duration of travel restrictions and shutdown of borders, although the outlook remains highly uncertain (the scenarios are not forecasts and should not be interpreted as such)".

Undoubtedly, tourism is one of the forces that drives economic growth (Chen and Ioannides 2020), alleviates poverty in developing economies, creates jobs and generates tax revenue (UNWTO 2015). However, no country is devoid of corruption which, as discussed below, is related to tourism in the form of an inverted U-shaped curve.

The present paper aims to contribute to the literature on the relationship between corruption and tourism demand in multiple ways. The first research question the paper addresses relates to the direct relationship between corruption and tourism arrivals considering the likelihood of a linear or a nonlinear effect. Should a nonlinear relationship exist, the second aim of the paper is to examine if the "greasing the wheels" and the "sanding the wheels" hypotheses are valid which imply that tourism demand initially increases as corruption increases (greasing the wheels) and after a certain threshold level of corruption, tourism demand decreases (sanding the wheels). Finally, the third aim of the paper is to examine not only the direct effect of corruption on tourism demand under a low and a high corruption regime but also the indirect effect of corruption through the impact of other politico-socio-economic variables on tourism demand within these corruption regimes, a question which had not been empirically addressed before.

According to the results, the null hypothesis of a linear model against the alternative of a nonlinear threshold model with two regimes is strongly rejected. Furthermore, the "greasing the wheels" and the "sanding the wheels" hypotheses are confirmed which imply that the effect of corruption on tourism demand is positive in the low corruption regime and negative in the high corruption regime. In addition, a heterogeneous relationship is also found between various other politico-socio-economic variables and tourism demand in the low and high corruption regimes. 
The rest of the paper is organized as follows. Section 2 reviews the relevant literature, while Sect. 3 describes the aims of the project, the data, and the model used in the study. Section 4 reports and discusses the main empirical results, while Sect. 5 examines the robustness of the results. Finally, Sect. 6 discusses policy implications and concludes the paper.

\section{Literature review}

\subsection{Corruption}

Regarding corruption, Kaufman and Vicente (2011) challenged the traditional definition of corruption as the "abuse of public office for private gain" arguing that there is a need to distinguish between illegal corruption, legal corruption, and no-corruption. In attempting to disentangle illegal and legal corruption, the same authors proposed a theoretical model by defining corruption as a "collusive agreement" or connections between the elite. The same authors refer to private sector agents and politicians who are involved in an exchange of favours over time. Once legislation protecting corruption is enacted and enforced, then legal corruption is created. This is known as "state capture", i.e. passing legislation that favours few and selected individuals or organizations.

In addition to the private sector and politicians partaking in state capture, public officials may also create opportunities for bribes due to their discretionary powers (Swaleheen 2011). Thus, public officers act as independent monopolists (Shleifer and Vishny 1993) who seek bribes in return for doing their work and managers, rather than working productively, end up allocating more time and company resources to pay a bribe or kickback (Kaufman et al. 1998; Kaufman and Wei 2000). It has been argued that politicians may be "discriminating against firms with low bargaining power to maximize the private interests of politicians and bureaucrats" (Hellman et al. 2000: p. 2). Thus, stakeholders in the tourism industry are often aware of the inequalities created when firms partake in capture or other forms of corruption since the repercussions on the tourism industry are pervasive.

Corruption is a "hidden crime". A number of measurement tools attempt to quantify the extent of corruption practices. Hart (2019: p. 8) noted that "some count reported victimization ('experience'); others survey opinions of experts and broader populations ('perceptions') while others track certain types of administrative data". Two measurement systems selected to be used by the current authors are the Corruption Perception Index (CPI) published by Transparency International (TI) and the International Country Risk Guide (ICRG) published by the PPRS Group.

Transparency International scores countries on how corrupt their public sectors are perceived to be by public officials and politicians. The CPI is a composite index drawing on corruption-related data in expert surveys carried out by a variety of reputable institutions, yielding a CPI score from 0 to 100 . Countries that have a high score means they have low perceived corruption such as New Zealand and Denmark with a score of 87 as opposed to Somalia that has a score of 9. 
The ICRG has been published since 1988 by the PRS Group and is a "measure of corruption within the political system that threatens foreign investment by distorting the economic and financial environment, reducing the efficiency of government and business by enabling people to assume positions of power through patronage rather than ability, and introducing inherent instability into the political process" (Swaleheen 2011: p. 31). This measure looks at political, financial and economic risk variables. Schwindt-Bayer and Tavits (2016) pointed out that the ICRG is a component of CPI and the World Bank's corruption measurement. The same authors use ICRG as it "offers the most complete time-series for the largest number of countries and it is comparable over time. It is based on expert survey, the content of the measure stays the same for each year, and the scores for one country are independent from those of other countries" (p.46). Furthermore, other researchers (Charron 2011; Yadav 2012), who used ICRG, have maintained that ICRG is comparable across time and countries and can be used in time-series analyses, whereas the CPI provides a snapshot with less capacity to offer year-to-year trends (Campos and Pradhan 2007). Furthermore, in arguing against the use of CPI, Hough (2016) has argued that this measurement system ignores private corruption, like the Libor case in Britain and the VW emissions in the USA.

A limitation of both the CPI and the ICRG is that neither of them is a direct measure of a country's corruption. Nevertheless, the ICRG is considered "a good proxy of corruption" (Swaleheen 2011: p. 31), whereas the CPI is a composite index of corruption perception. Thus, the current authors, unlike Saha and Yap (2015) and Lv and Xu (2017), have used the ICRG data rather than the CPI.

The negative consequences of corruption have been reported by a number of researchers, and they include hindering economic growth and fostering inefficiency (Shleifer and Vishny 1993; Mauro 1995; Kaufmann and Kraay 2002; Santos et al. 2019). Interestingly, it has been found that corruption increases a firm's sales and exports in low-income economies but has the opposite effect in middle- and highincome countries (Imran et al. 2019). Furthermore, corruption disrupts international trade and investment as well as public policy (Mauro 1995; Gastanaga et al. 1998; Wei 1999; Zhao et al 2003) and impacts adversely on private sector development, leads to misallocation of resources (Ades and Di Tella 1999) and "hamper innovation efforts" (DiRienzo and Das 2015: p. 54) as it erodes trust and increases transaction costs and, also, undermines mega event support (Santos et al. 2019).

Contrary to the above view, there is an argument that "corruption can actually be very helpful for firms in the tourism industry" (Ekine 2018: p. 48). More specifically, it has been argued that corruption can be beneficial because "greasing the wheel" accelerates processes or sidesteps regulations (Bicchieri and Duffy 1997) or government employees may thus have an incentive to work harder if they ask for bribes (Saha and Yap 2015). Before addressing the nature of the relationship between tourism and corruption, let us first briefly examine a number of studies which have reported both positive and negative correlates of tourism. 


\subsection{Corruption and tourism relationship}

Conflicting views have been expressed regarding the relationship between corruption and tourism. Some (e.g. Huntington 1968) have argued that corruption "greases the wheels" (i.e. it impacts positively on tourism), while others (e.g. Lau and Hazari 2011) have proposed that it "sands the wheels". Furthermore, other authors have proposed that both the opposite viewpoints are correct and, in fact, the relationship between corruption and tourism is an inverted U-shaped curve (Saha and Yap 2015; Demir and Gozgor 2017; Lv and Xu 2017). Let us examine the three perspectives.

As Harris (2012) reminds us, fraud and corruption are prevalent in the tourism industry with foreign tourists being the main victim. Interestingly, it has also been argued that "greasing the wheels" can increase efficiency (Lien 1986) because it decreases the time waiting in queues (Lui 1985) and can be beneficial in countries "where other aspects of governance are ineffective" (Méon and Sekkat 2005: p. 70). Thus, supporters of this theory maintain that where there is low quality of government in order to reduce the inconvenience caused by unnecessary bureaucracy, greasing of the wheels is necessary. However, it should be noted in this context that corruption is likely to add costs to the price of a travel product since the payment of a bribe will increase the cost of the product and this cost will be passed on the consumer.

Méon and Sekkat (2005: p. 91) have also found that weak law enforcement, an unproductive government and political violence create "sand in the wheels". For their part, Assaf and Josieassen (2012) argued that where there is corruption, countries are unable to develop their tourism industry despite its cultural and environmental heritage, a view also supported by Yap and Saha (2013).

Support for the argument that an increase in a country's perceived corruption has a negative effect on its inbound tourism can be found in Poprawe's (2015) study which established that the effect of corruption on total tourist arrivals is negative in 100 countries. Similarly, Das and Dirienzo (2010) reported that a decrease in corruption affected positively tourism competitiveness in 119 countries. In fact, Lau and Hazari (2011) and Poprawe (2015) did not only find an inverse relationship between corruption and tourism arrivals but quantified the impact on tourism. More specifically, both studies have found that an one-point decrease in corruption, utilizing the CPI, leads to 8\% (by Lau and Hazari 2011) and 6-7\% (by Poprawe 2015) higher tourist inflows. This relationship proved to be correct in the case of Cyprus in the summer of 2017. Cyprus' CPI score in January 2017 was higher by 2 points, and utilizing the Cyprus Statistical Service, tourism revenue in 2017 increased by $15.3 \%$ compared to the corresponding period in 2016 as tourism arrivals (TA) increased by $14.7 \%$ outnumbering the number of tourist arrivals on the island for years; thus, the predictions were proved to be correct. However, the increase in tourism arrivals may be attributable to other politico-socioeconomic factors as well at the time, for instance terrorist incidents in neighbouring Egypt and Turkey the year before, diverting a number of tourists to Cyprus. Thus, it can be argued that a country's corruption score is not the only variable impacting on tourism arrivals.

Focusing on the nonlinear relationship between corruption and tourism demand, Demir and Gozgor (2017) found that the level of relative corruption (i.e. the difference 
between the corruption in the country of the tourist's departure and the destination country) affects negatively inbound tourism in Turkey; in other words, more tourists visit Turkey from countries which are as corrupt or more corrupt than Turkey. Saha and Yap (2015) utilized data generated with the CPI methodology prior to 2012 (when TI's CPI score ranged from 0 to 10) and reported that the turning point of most to least corrupt country on the inverted U-curve is 6.7. The inverted $U$ curve illustrates that "corruption level does reduce tourism demand only after a threshold of corruption" (p. 280). Thus, both the "greasing the wheels" and "sanding the wheels" arguments are applicable. Likewise, Lv and Xu (2017) reported a nonlinear relationship between corruption and tourism demand in 62 countries over the period 1998-2011 with the relationship being significant at the 50th and 75th quantiles. Lv and Xu's study is similar to Saha and Yap as both utilize data which had been created using the old methodology of Transparency International's Corruption Perception Index. However, in view of the 2012 change of the CPI calculation methodology for calculating a country's CPI, the applicability of the results reported by Saha and Yap's (2015) and $\mathrm{Lv}$ and $\mathrm{Xu}$ (2017) finding concerning the turning point on the inverted U-curve is not applicable post-2011.

\section{Aims of the present study and methodology}

It can be seen from the preceding discussion of the literature that despite efforts by the previous authors to capture the nonlinear relationship between corruption and tourism arrivals, none of them adequately tested the presence of nonlinearity and none have considered the impact of other determinants within the different corruption regimes. For example, what is the effect of inflation on tourism arrivals when corruption is low/high?

The present study aims to fill this gap and contribute to the literature on the relationship between corruption and tourism by analysing the effect of different politico-socio-economic variables on tourism demand in low and high corruption regimes. Drawing also on Hansen (2017) and Kourtellos et al. (2016) where the threshold variable and the regressors are considered endogenous ensuring a statistically adequate model, the aims of the study reported have been to:

1. Ascertain the nature of the relationship between corruption and tourism;

2. Identify any nonlinear effects of corruption on tourism demand and, thus, test the "greasing-the-wheels" and "sanding-the-wheels" hypotheses by finding a threshold point; and finally,

3. Investigate the effect of different politico-socio-economic variables on tourism, within different corruption regimes by means of a Panel Threshold Regression Model.

The current paper utilizes improved methodology to that of other researchers and can be said to contribute significantly to theory since:

1. ICRG data are used rather than the CPI as the former overcomes limitations of CPI.

2. It covers a longer period of time (2001-2018) than other researchers. 
3. It utilizes a Panel Threshold Model rather than a linear model with a quadratic specification (Saha and Yap 2015) or a quantile regression (Lv and Xu 2017).

4. The other researchers have not empirically tested adequately for the presence of nonlinearity, and none have considered the impact of other determinants within different corruption regimes.

The documentation of a nonlinear relationship between corruption and tourism demand which can be modelled via a Panel Threshold Regression Model ensures not only a statistically adequate model but also confirms the theoretical predictions of Mauro $(1995,2002)$ for the presence of multiple equilibria in corruption and economic growth and similarly between corruption and tourism, since tourism constitutes a share of GDP.

\subsection{Data description and the tourism demand model}

Regarding the variables used for the statistical analysis, the authors utilized data from the World Tourism Organization (WTO) and particularly Tourist Arrivals and Tourism Receipts as proxies for the tourism demand. For the tourism demand determinants, data are used from (a) World Bank-World Development Indicators (WDI) and more precisely macroeconomic variables, GDP per capita, Trade Openness and Inflation, and (b) the International Country Risk Guide (ICRG) and specifically, measures of political (corruption, law and order, civil disorder, civil war, ethnic tensions, foreign pressures, military in politics, and religious tensions) and economic institutions (economic and financial risk rating and the risk for exchange rate stability). A detailed description of the variables and their source is given in Table 4 in the Appendix, whereas Table 5 presents the summary statistics for the pooled data.

GDP per capita measures the propensity and economic performance of a country and has been extensively used in studies examining tourists' arrivals (Leitão 2010; Poprawe 2015; Santana-Gallego et al. 2016). Surugiu et al. (2011) found a positive relationship between tourism demand and GDP of tourists' origin country, indicating the impact of GDP on tourists' decision for travelling. Openness to trade is a variable that examines how a country's trade connectedness to international markets influences tourists' arrivals to a destination. In support of Ibrahim (2011) writing about Egypt, Poprawe (2015) also reported that openness to trade impacts positively on tourism arrivals. Similarly, Leitão (2010) found that bilateral trade influenced significantly tourism arrivals in Portugal. However, openness to trade was found to be an insignificant variable with positive impact on tourism arrivals in Malaysia (Habibi et al., 2009). Unfortunately, however, on the basis of the available information provided in the studies it is not possible to account for the conflicting findings concerning the effect of openness to trade in different countries.

Predictably, perhaps, Meo et al. (2018) found in their study that an increase in inflation affects tourism demand negatively as tourists find a destination too expensive for them, while Naidu et al. (2017) reported that inflation affects negatively the tourism output in the medium and long term. Also as might be expected, exchange rate risk has been found by a number of studies to impact adversely on tourism arrivals 
(Garin-Munoz and Amaral 2000; Salman 2003; Hanafiah and Harun 2010). Examining the impact of the exchange rate between Mauritian price and US dollar using relative prices, Khadaroo and Seetanah (2007) found that relative price influences the decision of tourists travelling from Asia and Africa but not for tourists from Europe and America, emphasizing the importance of maintaining a relatively stable exchange rate in order to attract tourist arrivals (De Vita 2014).

The way political institutions in a country function undoubtedly impacts on the international image of that country. Neumayer (2004) argued that tourists are willing to travel to destinations where they will feel safe to enjoy their holidays without fear of bodily harm. Similarly, Feridun (2011) and Altindag (2014) support the existence of an inverse relationship between violent crimes and incoming tourists. Henderson (2003) and Yap and Saha (2013) reported that military involvement in politics can be a disincentive for tourists as it can result in lack of free movement in the nation and civil rights. However, a number of other authors (Larsen et al. 2009; Boakye 2010; Papathanassis 2016) have maintained that tourists are likely to return to holiday destinations and recommend them to others regardless of crime and other safety concerns to potential tourists. In support of that point of view, when Nonthapot and Lean (2013) examined the political crisis of Lao over the period 2008-2010, they found no effect on tourism arrivals.

Following Durlauf et al. (2008) and other scholars (Abed and Gupta 2003; Chong and Gradstein 2007; Yadav and Mukherjee 2016), the authors have rescaled corruption (and all ICRG variables), between 0 and $1(0 \leq \mathrm{x} \leq 1)$, where the lowest point 0 indicates low corruption and the highest point 1 , high corruption, "for comparability and ease of interpretation" (Chan et al. 2019).

Finally, countries that did not satisfy the selection criteria (in terms of the presence of the variables addressed and time span considering that the estimation requires a balanced panel) were excluded, leaving 83 countries for the period 2001-2018 (see Table 6 in the Appendix).

Following the literature (Song and Li 2008; Poprawe 2015; Saha and Yap 2015; Lv and $\mathrm{Xu}$ 2017), Tourist Arrivals (TA) was set as the baseline for the Tourism Demand Model which is defined as the number of tourists who travel to a country other than that in which they have their usual residence, which is outside their usual environment, for no more than 12 months and whose main purpose in visiting is other than an activity paid for within the country visited. Then, using a standard Fixed Effects balanced panel over the period 2001-2018 and for 83 countries the suggested Linear Tourism Demand Model will take the form of

$$
y_{i t}=\mu_{i}+\beta^{\prime} x_{i t}+e_{i t}
$$

where the dependent variable $y_{i t}$ is a scalar and measures the annual growth rate of tourist arrivals, $x_{i t}$ is a $k \times 1$ vector of tourism demand determinants, $\beta$ is a $k \times 1$ vector of unknown parameters, $e_{i t}$ is an i.i.d. error term for country $i=1,2, \ldots, N$ and time $t=1,2, \ldots, T$.

To address any issues of non-stationarity, we follow Hadri (2000), Levin et al. (2002) and Im et al. (2003) and implement three alternative panel unit root tests. According 
Table 1 Threshold tests and threshold estimates—tourist arrivals

\begin{tabular}{lllll}
\hline Threshold variable & $P$ value & Threshold & $\mathrm{n} 1$ & $\mathrm{n} 2$ \\
\hline Corruption (single threshold) & 0.0014 & 0.5208 & 634 & 860 \\
Corruption (double threshold) & 0.6583 & 0.5903 & - & - \\
\hline
\end{tabular}

to the results, all the variables in (1), which are calculated in annual growth rates, are stationary. ${ }^{1}$

In the spirit of Hansen (1999, 2000, 2017), Caner and Hansen (2004) and Kourtellos et al. (2016), we apply the static threshold GMM of Seo and Shin (2016), and the Panel Fixed Effects Threshold Tourism Demand Model generalizes the linear model in (1) by allowing for the presence of multiple regimes. In particular,

$$
y_{i t}= \begin{cases}\mu_{i}+\beta_{1}^{\prime} x_{i t}+e_{i t}, & q_{i t} \leq \gamma \\ \mu_{i}+\beta_{2}^{\prime} x_{i t}+e_{i t}, & q_{i t}>\gamma\end{cases}
$$

where $\gamma$ is the scalar threshold parameter or sample split value and $\left(\beta_{1}^{\prime}, \beta_{2}^{\prime}\right)$ is the vector of regression coefficients for the low and high regime, respectively. Therefore, the threshold model sorts the data into two groups of observations based on whether the threshold variable $q_{i t}$, namely corruption, is above or below the threshold parameter (sample split) $\gamma$. Alternatively, (2) can be expressed in a single equation as

$$
y_{i t}=\mu_{i}+\beta_{1}^{\prime} x_{i t} \mathrm{I}\left(q_{i t} \leq \gamma\right)+\beta_{2}^{\prime} x_{i t} \mathrm{I}\left(q_{i t}>\gamma\right)+e_{i t}
$$

where $I($.$) is the indicator function. In this setting, we allow for the threshold variable$ $q_{i t}$ and the set of the determinants $x_{i t}$ to be endogenous and appropriately instrumented using their lag values.

Estimation of the Threshold Tourism Demand Model requires first to determine if the threshold effect is statistically significant. Seo and Shin (2016) propose a bootstrap test for the null hypothesis of a linear model based on a supremum Wald statistic.

In practice, the presence of a nonlinear relationship between corruption and tourism demand is first tested by estimating the particular threshold/turning point, and then, uncovering the effect of corruption and all the other variables on tourism demand under the different corruption regimes by estimating a Panel Threshold Model.

\section{Empirical results}

The first aim of the study is to identify the nature of the relationship, linear or nonlinear, between corruption and tourism demand using a threshold test.

Table 1 shows the results of the threshold test for tourism arrivals considering the presence of one and two thresholds. The first column of the table shows the number of

\footnotetext{
1 The panel unit root results are available upon request.
} 
thresholds/splits under consideration for corruption, then the corresponding $\mathrm{p}$ value for the null hypothesis of a linear model against the alternative of a threshold, the threshold estimate and the sample sizes of the two regimes.

Table 1 presents the threshold test with the corresponding $p$ value and threshold estimate for tourist arrivals for the null hypothesis of a linear model against the alternative of a threshold.

According to the results $(p$ value $=0.0014$ ), the linear model null hypothesis is strongly rejected for the presence of one threshold/split. The authors also report the estimated corruption threshold point which is 0.5208 , as well as, the number of observations included in the low (below 0.5208 ) and the high corruption regime (above 0.5208 ) which are 634 and 860, respectively. On the other hand, the p value for the presence of a second threshold/split equals to 0.6583 , a result which was robust under different model specifications. Justifiably, then, it can be inferred that "there is a nonlinear relationship between corruption and tourism arrivals" confirming Saha and Yap (2015: p. 276) based on only one threshold in all of the regression relationships.

Table 2 shows the threshold regression estimation for the two regimes. The second column in Table 2 illustrates the regression coefficient and the corresponding robust standard errors for the Linear Fixed Effects Panel Model (which was decisively rejected) for comparison reasons, whereas the remaining columns present the regression coefficients and robust standard errors for the low and high corruption regime, respectively, in the context of a Panel Threshold Model. Regarding the effect of corruption and all the other politico-socio-economic variables on tourism arrivals in the linear Fixed Effects model, corruption has a strong negative effect on tourism arrivals $(-0.2532)$ with significance of $5 \%$ which supports the sand-in-the-wheel hypothesis, i.e. that high levels of corruption result in lower tourists' arrivals in destinations. The results in Table 2 also provide support for the hypotheses that tourists are significantly less likely to visit a country with civil war, ethnic and religious tensions, increased financial risk and inflation. However, tourists are more likely to visit a destination with higher GDP per capita or openness to trade.

Applying the Panel Threshold Model emphasizes the presence of the parameter heterogeneity in the sense that the effect of corruption on tourism arrivals is not exactly negative as in the linear model, but, rather, it depends on the level of corruption (below or above 0.5208), yielding a nonlinear relationship between corruption and tourism arrivals in the form of an inverted-U-shape curve.

Considering the model specification with all the explanatory variables included, all else being equal, higher levels of corruption result in lower tourism arrivals ( -0.3677 ) for countries in the high corruption regime (above 0.5208), as the sandin-the-wheel view suggests. However, for countries with better quality institutions, particularly countries in the low corruption regime (below 0.5208), corruption has a significant positive effect (0.4393) on tourism arrivals emphasizing the grease-inthe wheel hypothesis, thus achieving the second aim of the paper. Importantly and in support of Saha and Yap (2015: p. 280), the results indicate the threshold point where corruption stops being the grease "in the wheel" and becomes the sand "in the wheel" with adverse effect on tourism arrivals. It is also important to note that the negative coefficient of corruption in the high corruption regime is notably larger ( $0.3677)$ than the corruption coefficient in the linear model $(-0.2532)$, indicating the 


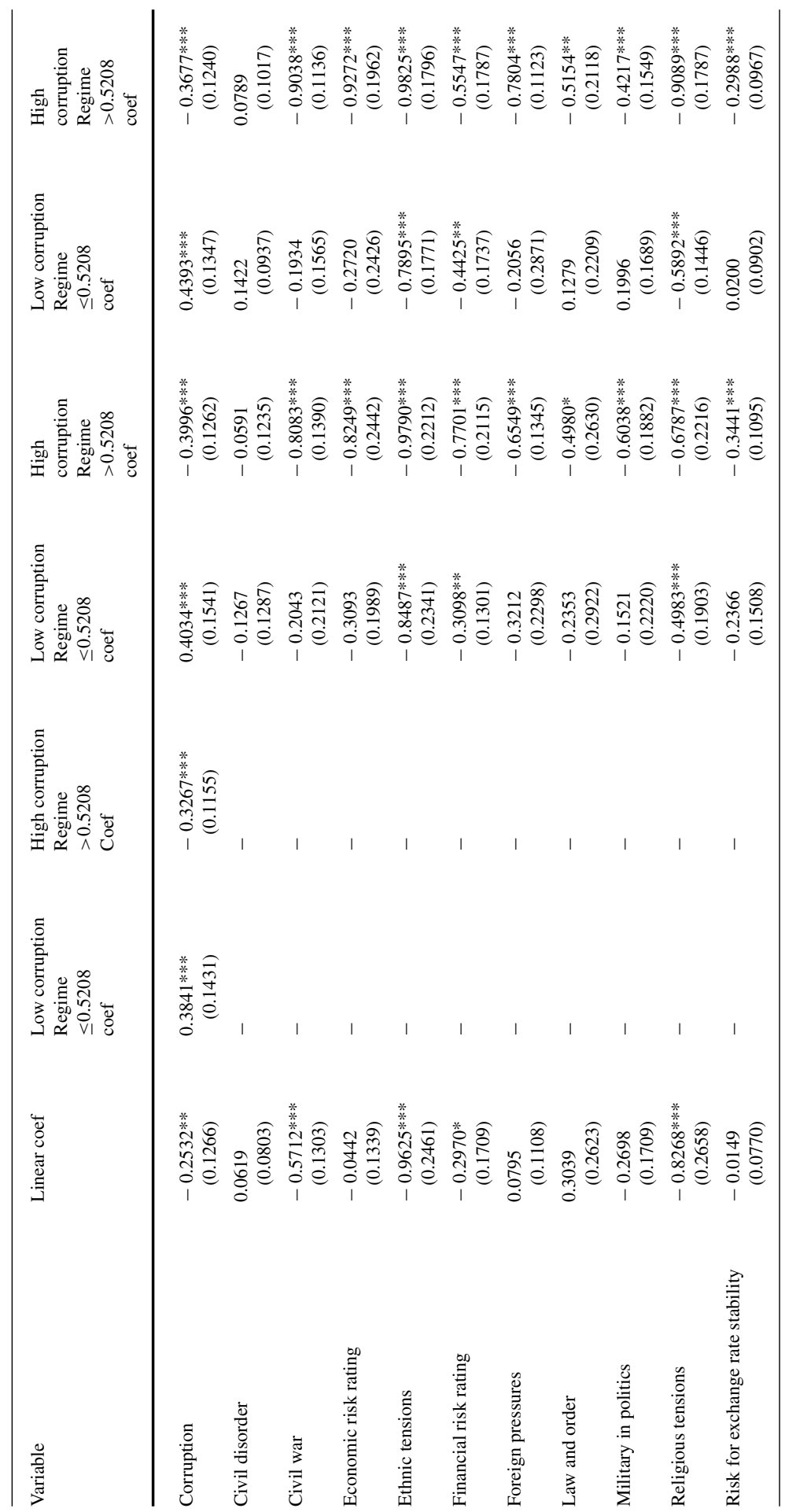




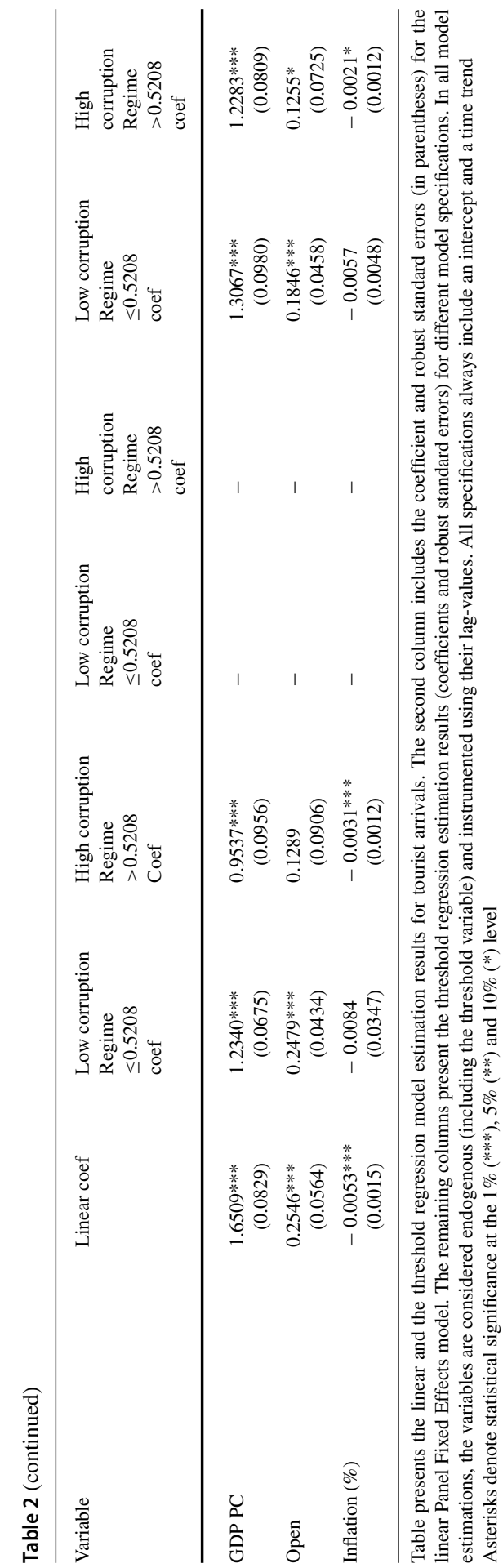


detrimental effects of bad institutions on tourism demand. This is illustrated in Table 2 where a calculation of the average arrivals in the low corruption regime is twice those in the high corruption regime, i.e. average tourism arrivals for low corruption regimes is $12,854,000$ and $6,646,000$ for high corruption regimes.

The third aim of the study is to investigate the effect of various politico-socioeconomic variables on tourism, within different corruption regimes in the context of a Panel Threshold Regression Model. The results in Table 2 support the presence of parameter heterogeneity not only of corruption on tourism demand, but also of the other determinants as well.

Tourists are less likely to visit countries characterized by internal conflicts, economic and political risks. In particular, based on the results presented in columns 7 and 8 in Table 2, tourists will avoid countries with civil wars, increased economic, exchange rate and law and order risks, with military involvement in politics and foreign pressures, all statistically significant in the high corruption regime. Further, ethnic and religious tension, as well as increased financial risk, reduce tourist arrivals significantly, especially in the high corruption regime. Focusing on the effect of the macroeconomic variables, tourists are more likely to visit a country with higher GDP per capita and more open to trade, a result which is larger and stronger in the low corruption regime. Finally, inflation has a negative effect on tourism demand but only the high corruption regime.

Thus, the paper has achieved its third aim as well, in identifying the politico-socioeconomic factors impacting tourism in different corruption regimes (see Table 3). This is a significant contribution to theory as no other researchers have found this relationship within the two corruption regimes.

\section{Robustness}

In testing the robustness of the results obtained, the authors have carried out multiple robustness tests reported in the Online Appendix.

In the first, the authors compared the corruption regime classification (low-below 0.5208 , or high - above 0.5208 ) of each country (see Table 3) with Transparency International's CPI ranking for the year 2018, which is the last year in the data set tested for this paper. It was interesting to find that countries ranked by Transparency International in their 2018 CPI with a score higher than 45 were also found by the current authors to be ranked as countries in the low corruption regime. Conversely, countries like Armenia, Algeria, Tanzania, Iran, Russia and Sudan that had a score below 45 were ranked in the high corruption regime by the authors.

To further test for robustness, tourist arrivals was replaced with tourism receipts which include all transactions related to the consumption of goods and services by international visitors. Based on the findings from Tables 1 and 2 in the Online Appendix, similar results were obtained, with the difference in the threshold being 0.5000 rather than 0.5208 as eight countries were missing tourism receipts data and, consequently, the sample is only 75 countries in the robustness test rather than 83 . 
Table 3 Countries within the corruption regimes

\begin{tabular}{|c|c|c|}
\hline Country & Low corruption regime & High corruption regime \\
\hline Angola & & 2001-2018 \\
\hline Armenia & & 2001-2018 \\
\hline Austria & 2001-2018 & \\
\hline Bahamas & 2001-2018 & \\
\hline Belarus & & 2001-2018 \\
\hline Belgium & 2001-2018 & \\
\hline Bolivia & 2001 & 2002-2018 \\
\hline Brazil & 2003, 2009-2011 & 2001-2002, 2004-2008, 2012-2018 \\
\hline Bulgaria & 2017-2018 & 2001-2016 \\
\hline Burkina Faso & & 2001-2018 \\
\hline Canada & 2001-2018 & \\
\hline Chile & 2001-2002, 2005-2018 & 2003-2004 \\
\hline China & & 2001-2018 \\
\hline Colombia & 2003-2005, 2009-2011 & 2001-2002, 2006-2008, 2012-2018 \\
\hline Congo (Republic) & 2001-2002 & 2003-2018 \\
\hline Costa Rica & 2001-2002, 2015-2017 & 2003-2014, 2018 \\
\hline Croatia & 2001-2004, 2010-2011, 2015-2018 & 2005-2009, 2012-2014 \\
\hline Cyprus & 2001-2018 & \\
\hline Denmark & 2001-2018 & \\
\hline Dominican Republic & 2001 & 2002-2018 \\
\hline Egypt & & 2001-2018 \\
\hline Estonia & 2001-2018 & \\
\hline Finland & 2001-2018 & \\
\hline France & 2001-2018 & \\
\hline Gambia & 2001-2004 & 2005-2018 \\
\hline Germany & 2001-2018 & \\
\hline Greece & 2001 & $2002-2018$ \\
\hline Guyana & 2001-2005 & 2006-2018 \\
\hline Haiti & & 2001-2018 \\
\hline Hong Kong & 2001-2018 & \\
\hline Hungary & 2001-2018 & \\
\hline Iceland & 2001-2018 & \\
\hline India & & 2001-2018 \\
\hline Ireland & 2002-2003, 2005-2018 & 2001, 2004 \\
\hline Israel & 2001-2018 & \\
\hline Italy & 2001,2018 & 2002-2017 \\
\hline Jordan & 2001-2011, 2015-2018 & 2012-2014 \\
\hline Latvia & 2015-2017 & 2001-2014, 2018 \\
\hline Lithuania & $2001,2015-2018$ & 2002-2014 \\
\hline
\end{tabular}


Table 3 (continued)

\begin{tabular}{|c|c|c|}
\hline Country & Low corruption regime & High corruption regime \\
\hline Luxembourg & 2001-2018 & \\
\hline Madagascar & 2001-2011 & 2012-2018 \\
\hline Malawi & 2001 & 2002-2018 \\
\hline Malaysia & & $2001-2018$ \\
\hline Mali & 2003 & 2001-2002, 2004-2018 \\
\hline Malta & 2001-2018 & \\
\hline Mexico & 2001 & 2002-2018 \\
\hline Moldova & & 2001-2018 \\
\hline Mongolia & & 2001-2018 \\
\hline Morocco & 2001-2004, 2006-2011, 2017-2018 & $2005,2012-2016$ \\
\hline Mozambique & 2001-2018 & \\
\hline Myanmar & & 2001-2018 \\
\hline Netherlands & 2001-2018 & \\
\hline New Zealand & 2001-2018 & \\
\hline Nicaragua & 2001 & 2002-2018 \\
\hline Niger & & 2001-2018 \\
\hline Norway & 2001-2018 & \\
\hline Oman & 2015-2018 & 2001-2014 \\
\hline Panama & & 2001-2018 \\
\hline Paraguay & & 2001-2018 \\
\hline Peru & 2001 & 2002-2018 \\
\hline Philippines & & $2001-2018$ \\
\hline Poland & 2013-2018 & 2001-2012 \\
\hline Portugal & 2001-2018 & \\
\hline Qatar & 2013-2018 & 2001-2012 \\
\hline Saudi Arabia & 2015-2018 & 2001-2014 \\
\hline Sierra Leone & 2001 & 2002-2018 \\
\hline Singapore & 2001-2018 & \\
\hline Slovenia & 2001-2018 & \\
\hline South Africa & 2001, 2010-2011 & 2002-2009, 2012-2018 \\
\hline Spain & $2001-2018$ & \\
\hline Sri Lanka & 2001-2004 & 2005-2018 \\
\hline Sudan & & 2001-2018 \\
\hline Tanzania & 2007-2009 & 2001-2006, 2010-2018 \\
\hline Thailand & & 2001-2018 \\
\hline Togo & & 2001-2018 \\
\hline Trinidad and Tobago & 2001 & 2002-2018 \\
\hline Tunisia & 2001 & 2002-2018 \\
\hline Turkey & & 2001-2018 \\
\hline
\end{tabular}


Table 3 (continued)

\begin{tabular}{lll}
\hline Country & Low corruption regime & High corruption regime \\
\hline Ukraine & & $2001-2018$ \\
United Kingdom & $2001-2018$ & \\
United States & $2001-2018$ & \\
Uruguay & $2001-2018$ & $2001-2004,2012-2018$ \\
Zambia & $2005-2011$ & \\
\hline
\end{tabular}

To establish further our results, the third robustness exercise includes replacing corruption from ICRG with the Corruption Control Index from the Worldwide Governance Indicators. The control of corruption index captures perceptions of the extent to which public power is exercised for private gain, including both petty and grand forms of corruption, as well as "capture" of the state by elites and private interests. It also measures the strength and effectiveness of a country's policy and institutional framework to prevent and combat corruption. The variable ranges fro -2.5 indicating most corrupt/least effective to 2.5 indicating least corrupt/most effective.

According to the results in Table 3 in the Online Appendix, the linear model null hypothesis is strongly rejected for the presence of one threshold/split ( $p$ value 0.0033 ), whereas the presence of a second threshold is rejected ( $p$ value 0.4513 ). The estimated corruption threshold point is 0.2800 with 909 observations in the high corruption regime and 585 in the low corruption regime.

Table 4 in the Online Appendix reports the estimated threshold regression model for tourist arrivals and corruption control index. The results confirm the previous findings regarding the positive effect of corruption in the low corruption regime and the corresponding negative impact on tourist arrivals in the high corruption regime.

As a last robustness exercise, we address the issue of theory uncertainty by implementing Bayesian model averaging (BMA) since the effect of a particular regressor including corruption may vary across different model specifications. BMA was developed and studied from different scholars including Leamer (1978), Draper (1995), Kass and Raftery (1995), Raftery et al. (1997), Brock and Durlauf (2001), among others. Model averaging constructs estimates using information from all candidate models, and in particular, it forms a weighted average of model specific estimates where the weights are given by the posterior model probabilities. Based on Eq. (1), the BMA estimator takes the form of a weighted average of model-specific coefficient estimates:

$$
\hat{\beta}_{\mathrm{BMA}}=\sum_{m=1}^{M} w_{m} \hat{\beta}_{m}
$$

where $M=\left\{M_{1}, \ldots, M_{M}\right\}$ denotes the model space and the weights $W=$ $\left\{w_{1}, \ldots, w_{M}\right\}$ reflect the evidentiary support for each model given the data. The weights $\mathrm{W}$ are given by the posterior model probabilities computed using the Bayes' 
rule, such that each weight is the product of the integrated likelihood of the data given a model and the prior probability for a model. In our estimation, we assume a uniform model prior such that the prior probability that any variable is included in the true model is taken to be 0.5 . The corresponding model averaging variance estimator is given by

$$
\hat{V}_{\mathrm{BMA}}=\sum_{m=1}^{M} w_{m} \hat{V}_{m}^{\beta}+\sum_{m=1}^{M} w_{m}\left(\hat{\beta}_{m}-\hat{\beta}_{\mathrm{BMA}}\right)^{2}
$$

Using the posterior mean and variance $\hat{\beta}_{\mathrm{BMA}}$ and $\hat{V}_{\mathrm{BMA}}$, we calculate posterior $\mathrm{t}$-statistics and interpret them in the classical sense. In addition, we also report the posterior probability of inclusion (PIP) for each regressor which is computed as the sum of posterior probabilities of the models which contain that variable. Following Kass and Raftery (1995), we interpret the values of PIP as follows: PIP < 50\% indicates no evidence for an effect, $50 \%<$ PIP $<75 \%$ indicates weak evidence for an effect, $75 \%<\mathrm{PIP}<95 \%$ indicates positive evidence for an effect, $95 \%<\mathrm{PIP}<99 \%$ indicates strong evidence for an effect, and 99\% < PIP $<100 \%$ indicates decisive evidence for an effect. Table 5 in the Online Appendix presents BMA results for the linear and threshold model for tourist arrivals, which confirm the previous findings. Notably, corruption is still positive and statistically significant in the low corruption regime and negative and also significant in the high corruption regime with posterior probability of inclusion to be one.

\section{Conclusions}

Tourism has increased significantly over the years, and many countries today rely on it to drive their economic growth, create jobs and generate tax revenue. Studies have examined the impact on tourism arrivals of different factors, including corruption. Given that many countries are plagued by corruption, and at the same time they rely on tourism for their economic growth, knowing the exact nature of the relationship between corruption and tourism becomes imperative.

The findings indicate that corruption influences tourism demand both directly and indirectly. As confirmed by the present study, the effect of corruption on tourism arrivals can be either positive or negative, suggesting that the direct relationship between these variables is nonlinear, an issue that has received inadequate attention in the tourism demand literature. In support of Saha and Yap (2015: p. 276) and by (a) adopting the Panel Threshold Model and (b) using data for 83 countries for the period between 2001 and 2018, the data analysis yielded a nonlinear relationship between corruption and tourism arrivals. The second aim of the paper was to identify the threshold point where corruption stops greasing the wheel and becoming sanding the wheel, thus decreasing tourism arrivals.

In addition to determining the nature of the relationship between corruption and tourism demand, the third aim of the paper was to investigate the effect of various politico-socio-economic variables in the different corruption regimes and how they 
each affect tourism arrivals. Low corruption regimes are characterized by effective mechanisms for promoting integrity and preventing corruption by means of good anti-corruption legislation, good administration, integrity of civil servants and civil society participation.

Thus, tourists are significantly more likely to visit a low corruption regime country where the positive effect of GDP and openness to trade is stronger than the high corruption regime. By contrast, tourist arrivals are affected negatively from civil war, economic risk rating, foreign pressures, law and order, military in politics, exchange rate risk and inflation, factors which are significant only in countries with high corruption.

It can, thus, be justifiably argued that the study reported has achieved all its stated aims: it rejected the null hypothesis of no threshold (linear model) relationship between tourism and corruption, confirming also the theoretical predictions of Mauro for the presence of multiple equilibria in corruption and economic growth and similarly between corruption and tourism; estimated the turning point of corruption regime countries; and, unlike previous studies, went on to examine not only the effect of corruption on tourism arrivals, but also the effect of various different politico-economic-socio variables under both low and high corruption regimes.

Furthermore, it can also be rightly argued that the study reported fills a research gap in a number of ways. Firstly, concerning methodology, it improves on the existing empirical studies (Saha and Yap 2015; Demir and Gozgor 2017 and Lv and Xu 2017), by applying a threshold analysis (see Caner and Hansen 2004; Hansen 2017, 2000, 1999 and Kourtellos et al. 2016) and particularly the static threshold GMM of Seo and Shin (2016), to a large panel of countries for the first time. The present study shows statistically that the null hypothesis of a linear model is decisively rejected and the nonlinear relationship between corruption and tourism arrivals has been demonstrated using a Panel Threshold Model with one threshold point. Thus, the study provides new insights into the relationship between corruption and other variables. A key characteristic of this method is that the "variable of interest (corruption) is observable, but the position of the threshold is not known" (Polemis and Stengos 2018: p. 99) and it is based on a sample-splitting framework.

An important critique of previous studies was the subjective pre-selection of threshold value. The threshold analysis used in the current paper is not subject to that criticism as it follows an objective strategy for identifying and testing changes in the slope. In addition, this methodology allows testing for additional sample splits (thresholds), thus also exploring the presence of more than two corruption regimes (multiple corruption regimes).

A critical appraisal of the existing literature and the findings obtained in the present study point to a number of policy implications. Firstly, legislatures, technocrats and entities like Chambers of Commerce, tourism industry regulators or those responsible for formulating national strategies for economic growth ought to first tackle corruption if they wish to increase tourism arrivals. Secondly, addressing corruption effectively means implementing a holistic approach meaningfully by involving the stakeholders (Krambia-Kapardis 2016; Azim and Kluvers 2019) and including adherence to a code of conduct, ethical policies, implementation of social responsibility policies, applying ethical and transparent lobbying and implementing whistle-blowing procedures. 
Support for such an approach has also been voiced by Lyrio and Lunken (2018) who encourage tourists to come forward more when they witness corrupt practices on their holidays. By addressing corruption and endeavouring to place a country in the low corruption regime, tourism arrivals would be expected to increase when the other politico-socio-economic variables are taken into account.

Supplementary Information The online version contains supplementary material available at https://doi. org/10.1007/s00181-021-02193-2.

Funding No funding has been received for this paper.

Data availability Data are available upon request.

Code availability Code is available upon request.

\section{Declarations}

Conflict of interest All the authors declare that they have no conflicts of interest.

Open Access This article is licensed under a Creative Commons Attribution 4.0 International License, which permits use, sharing, adaptation, distribution and reproduction in any medium or format, as long as you give appropriate credit to the original author(s) and the source, provide a link to the Creative Commons licence, and indicate if changes were made. The images or other third party material in this article are included in the article's Creative Commons licence, unless indicated otherwise in a credit line to the material. If material is not included in the article's Creative Commons licence and your intended use is not permitted by statutory regulation or exceeds the permitted use, you will need to obtain permission directly from the copyright holder. To view a copy of this licence, visit http://creativecommons.org/licenses/ by/4.0/.

\section{Appendix}

See Tables 4, 5 and 6. 
Table 4 Variable description and data sources

Variable Description

Tourist arrivals

Tourism Receipts

Corruption

Control of Corruption Index

Civil Disorder

Civil War
International inbound tourists (overnight visitors) are the number of tourists who travel to a country other than that in which they have their usual residence, but outside their usual environment, for a period not exceeding 12 months and whose main purpose in visiting is other than an activity remunerated from within the country visited. When data on number of tourists are not available, the number of visitors, which includes tourists, same-day visitors, cruise passengers, and crew members, is shown instead. Sources and collection methods for arrivals differ across countries. In some cases, data are from border statistics (police, immigration and the like) and supplemented by border surveys. In other cases, data are from tourism accommodation establishments. For some countries, the number of arrivals is limited to arrivals by air and for others to arrivals staying in hotels. Some countries include arrivals of nationals residing abroad, while others do not. Caution should thus be used in comparing arrivals across countries. The data on inbound tourists refer to the number of arrivals, not to the number of people traveling. Thus, a person who makes several trips to a country during a given period is counted each time as a new arrival. In a logarithmic form. Source: World Tourism Organization (WTO). http://www2. unwto.org/en. Data access is restricted to subscribers

For destination countries, receipts from international tourism count as exports in the balance of payments (travel) of each country and cover all transactions related to the consumption of goods and services by international visitors, such as accommodation, food and drink, fuel, domestic transport, entertainment and shopping. They include transactions generated by same-day as well as overnight visitors. Receipts from same-day visitors can be substantial, especially in the case of neighbouring countries where shopping accounts for a large amount of spending by cross-border, same-day visitors. International tourism receipts (travel) do not include receipts from international passenger transport contracted from companies outside the travellers' countries of residence. Source: World Tourism Organization (WTO). http://www2.unwto.org/en. Data access is restricted to subscribers

A measure of corruption within the political system that is a threat to foreign investment by distorting the economic and financial environment, reducing the efficiency of government and business by enabling people to assume positions of power through patronage rather than ability and introducing inherent instability into the political process. Between 0 (high corruption) and 6 (low corruption). Rescaled between 0 (very clean) and 1 (highly corrupt).Source: International Country Risk Guide (ICRG). https://epub.prsgroup.com/ products/icrg-historical-data. Data access is restricted to subscribers

Control of corruption captures perceptions of the extent to which public power is exercised for private gain, including both petty and grand forms of corruption, as well as "capture" of the state by elites and private interests. It also measures the strength and effectiveness of a country's policy and institutional framework to prevent and combat corruption. Ranges from -2.5 (most corrupt/least effective) to 2.5 (least corrupt/most effective) Source: Worldwide Governance Indicators. https://info.worldbank.org/governance/wgi. Data access is open

"The potential risk to governance or investment from mass protest, such as anti-government demonstrations, strikes, etc. Between 0 (high risk) and 4 (low risk)". Rescaled between 0 (low risk) and 1 (high risk). Source: International Country Risk Guide (ICRG) https://epub.prsgroup.com/products/icrg-historical-data. Data access is restricted to subscribers

The actual or potential risk of civil war (where a rebel force, which holds territory, is in armed conflict with the security forces of the government, and where both forces are citizens of the state in which the conflict occurs). Between 0 (high risk) and 4 (low risk). Rescaled between 0 (low risk) and 1 (high risk). Source: International Country Risk Guide (ICRG). https://epub.prsgroup.com/products/icrg-historical-data. Data access is restricted to subscribers 
Table 4 (continued)

\begin{tabular}{ll}
\hline Variable & Description \\
\hline Economic Risk Rating & A means of assessing a country's current economic strengths and weaknesses. In general, \\
& where strengths outweigh weaknesses, a country will show low risk, and where \\
& weaknesses outweigh strengths, the economic risk will be high. To ensure comparability \\
& between countries, risk components are based on accepted ratios between the measured \\
& data within the national economic/financial structure, and then the ratios are compared, \\
& not the data. Risk points are assessed for each of the component factors of GDP per head \\
& of population, real annual GDP growth, annual inflation rate, budget balance as a \\
& percentage of GDP, and current account balance as a percentage of GDP. Risk ratings \\
& range from a high of 50 (least risk) to a low of 0 (highest risk), though lowest de facto \\
& ratings are generally near 15. Rescaled between 0 (low risk) and 1 (high risk). Source: \\
& International Country Risk Guide (ICRG). https://epub.prsgroup.com/products/icrg- \\
& historical-data. Data access is restricted to subscribers
\end{tabular}

Ethnic Tensions

Financial Risk Rating

Foreign Pressures

Law and Order

Military in Politics
A measure of the degree of tension attributable to racial, national, or language divisions. Between 0 and 6. Lower ratings near 0 (higher risk) are given to countries where tensions are high because opposing groups are intolerant and unwilling to compromise. Higher ratings, near 6 , are given to countries where tensions are minimal, even though such differences may still exist. Rescaled between 0 (low risk) and 1 (high risk). Source: International Country Risk Guide (ICRG). https://epub.prsgroup.com/products/icrghistorical-data. Data access is restricted to subscribers

A means of assessing a country's ability to pay its way by financing its official, commercial and trade debt obligations. To ensure comparability between countries, risk components are based on accepted ratios between the measured data within the national economic/financial structure, and then the ratios are compared, not the data. Risk points are assessed for each of the component factors of foreign debt as a percentage of GDP, foreign debt service as a percentage of exports of goods and services (XGS), current account as a percentage of XGS, net liquidity as months of import cover, and exchange rate stability. Risk ratings range from a high of 50 (least risk) to a low of 0 (highest risk), though lowest de facto ratings are generally near 20. Rescaled between 0 (low risk) and 1 (high risk). Source: International Country Risk Guide (ICRG). https://epub.prsgroup.com/ products/icrg-historical-data. Data access is restricted to subscribers

Actual or potential risk posed by pressures brought to bear on the government by one or more foreign states to force a change of policy. Such pressures can range from diplomatic pressures, through suspension of aid and/or credits, to outright sanctions. Between 0 (high risk) and 4 (low risk). Rescaled between 0 (low risk) and 1 (high risk). Source: International Country Risk Guide (ICRG). https://epub.prsgroup.com/products/icrghistorical-data. Data access is restricted to subscribers

Two measures comprising one risk component. Each sub-component equals half of the total. The "law" sub-component assesses the strength and impartiality of the legal system, and the "order" sub-component assesses popular observance of the law. Between 0 (high risk) and 6 (low risk). Rescaled between 0 (low risk) and 1 (high risk). Source: International Country Risk Guide (ICRG). https://epub.prsgroup.com/products/icrg-historical-data. Data access is restricted to subscribers

A measure of the military's involvement in politics. Since the military is not elected, involvement, even at a peripheral level, diminishes democratic accountability. Military involvement might stem from an external or internal threat, be symptomatic of underlying difficulties, or be a full-scale military takeover. Over the long term, a system of military government will almost certainly diminish effective governmental functioning, become corrupt, and create an uneasy environment for foreign businesses. Between 0 and 6 . Overall, lower risk ratings $(0)$ indicate a greater degree of military participation in politics. Rescaled between 0 (low participation) and 1 (high participation). Source: International Country Risk Guide (ICRG). https://epub.prsgroup.com/products/icrg-historical-data. Data access is restricted to subscribers 
Table 4 (continued)

\begin{tabular}{|c|c|}
\hline Variable & Description \\
\hline Religious Tensions & $\begin{array}{l}\text { A measure of religious tensions arising from the domination of society and/or governance } \\
\text { by a single religious group-or a desire to dominate-in a way that replaces civil law by } \\
\text { religious law, excludes other religions from the political/social processes, and suppresses } \\
\text { religious freedom or expressions of religious identity. The risks involved range from } \\
\text { inexperienced people imposing inappropriate policies to civil dissent or civil war. } \\
\text { Between } 0 \text { (high tensions) and } 6 \text { (low tensions). Rescaled between } 0 \text { (low tensions) and } 1 \\
\text { (high tensions). Source: International Country Risk Guide (ICRG). https://epub.prsgroup. } \\
\text { com/products/icrg-historical-data. Data access is restricted to subscribers }\end{array}$ \\
\hline
\end{tabular}

Risk for Exchange Rate Stability

GDPpc

Open

Inflation (\%)
Ranging from high \% change of either $0.0-9.9$ appreciation or depreciation of $0.1-4.9$ with risk points at 10.0 , to a midpoint of either appreciation at $50.0+$ or depreciation of $30.0-34.9$ with risk points at 5.0 to a low depreciation of $100.0+$ with 0.0 points. Between 0 and 10. The higher the points (at 10), the lower the risk for appreciation/depreciation. Rescaled between 0 (low risk) and 1 (high risk). Source: International Country Risk Guide (ICRG). https://epub.prsgroup.com/products/icrghistorical-data. Data access is restricted to subscribers

GDP per capita is gross domestic product divided by midyear population. GDP is the sum of gross value added by all resident producers in the economy plus any product taxes and minus any subsidies not included in the value of the products. It is calculated without making deductions for depreciation of fabricated assets or for depletion and degradation of natural resources. Data are in constant 2010 U.S. dollars. In a logarithmic form. Source: World Bank, World Development Indicators (WDI). http://datatopics.worldbank. org/world-development-indicators/. Data access is open

Trade is the sum of exports and imports of goods and services measured as a share of gross domestic product

Source: World Bank, World Development Indicators (WDI). http://datatopics.worldbank. org/world-development-indicators/.Data access is open

Inflation as measured by the consumer price index reflects the annual percentage change in the cost to the average consumer of acquiring a basket of goods and services that may be fixed or changed at specified intervals, such as yearly. The Laspeyres formula is generally used. Source: World Bank, World Development Indicators (WDI). http://datatopics. worldbank.org/world-development-indicators/. Data access is open 
Table 5 Descriptive statistics

\begin{tabular}{|c|c|c|c|c|}
\hline Variable & Mean & Standard diviation & Min & Max \\
\hline Tourist arrivals & 9280.13 & $15,430.8$ & 16.000 & $89,322.0$ \\
\hline Tourist arrivals (log) & 7.8293 & 1.8399 & 2.7726 & 11.4000 \\
\hline Tourism receipts & 9102.20 & $19,144.3$ & 3.0000 & $214,680.0$ \\
\hline Tourism receipts (log) & 7.7674 & 1.8622 & 1.0986 & 12.2769 \\
\hline Corruption & 0.5183 & 0.2043 & 0.0000 & 0.9167 \\
\hline Control of corruption index & 0.1963 & 1.0467 & -1.7200 & 2.4700 \\
\hline Civil disorder & 0.3126 & 0.1428 & 0.0000 & 0.8750 \\
\hline Civil war & 0.0650 & 0.1345 & 0.0000 & 1.0000 \\
\hline Economic risk rating & 0.2783 & 0.1036 & 0.0000 & 0.6025 \\
\hline Ethnic tensions & 0.3155 & 0.1985 & 0.0000 & 0.9167 \\
\hline Financial risk rating & 0.2565 & 0.1007 & 0.0308 & 0.6425 \\
\hline Foreign pressures & 0.2632 & 0.1559 & 0.0000 & 1.0000 \\
\hline Law and order & 0.3384 & 0.2116 & 0.0000 & 0.8333 \\
\hline Military in politics & 0.3037 & 0.2753 & 0.0000 & 1.0000 \\
\hline Religious tensions & 0.2092 & 0.1873 & 0.0000 & 0.8889 \\
\hline Risk for exchange rate stability & 0.0720 & 0.1222 & 0.0000 & 0.9250 \\
\hline Gdp pc (log) & 8.9091 & 1.5357 & 5.6094 & 11.6260 \\
\hline Open & 0.9430 & 0.6614 & 0.0017 & 4.4262 \\
\hline Inflation $(\%)$ & 5.1898 & 8.5780 & -60.4964 & 152.561 \\
\hline Obs: 1494 & & & & \\
\hline
\end{tabular}


Table 6 List of countries

\begin{tabular}{|c|c|c|}
\hline Angola & Latvia & Togo \\
\hline Armenia & Lithuania & Trinidad and Tobago \\
\hline Austria & Luxembourg & Tunisia \\
\hline Bahamas & Madagascar & Turkey \\
\hline Belarus & Malawi & Ukraine \\
\hline Belgium & Malaysia & UK \\
\hline Bolivia & Mali & USA \\
\hline Brazil & Malta & Uruguay \\
\hline Bulgaria & Mexico & Zambia \\
\hline Burkina Faso & Moldova & \\
\hline Canada & Mongolia & \\
\hline Chile & Morocco & \\
\hline China & Mozambique & \\
\hline Colombia & Myanmar & \\
\hline Congo (Republic) & Netherlands & \\
\hline Costa Rica & New Zealand & \\
\hline Croatia & Nicaragua & \\
\hline Cyprus & Niger & \\
\hline Denmark & Norway & \\
\hline Dominican Republic & Oman & \\
\hline Egypt & Panama & \\
\hline Estonia & Paraguay & \\
\hline Finland & Peru & \\
\hline France & Philippines & \\
\hline Gambia & Poland & \\
\hline Germany & Portugal & \\
\hline Greece & Qatar & \\
\hline Guyana & Saudi Arabia & \\
\hline Haiti & Sierra Leone & \\
\hline Hong Kong & Singapore & \\
\hline Hungary & Slovenia & \\
\hline Iceland & South Africa & \\
\hline India & Spain & \\
\hline Ireland & Sri Lanka & \\
\hline Israel & Sudan & \\
\hline Italy & Tanzania & \\
\hline Jordan & Thailand & \\
\hline
\end{tabular}




\section{References}

Abed G, Gupta S (2003) Governance, corruption, and economic performance. Int Monet Fund Ades A, Di Tella R (1999) Rents, competition and corruption. Am Econ Rev 89(4):982-993 Altindag DT (2014) Crime and international tourism. J Labour Res 35(1):1-4

Assaf AG, Josiassen A (2012) Identifying and ranking the determinants of tourism performance: a global investigation. J Travel Res 51(4):388-399

Azim MI, Kluvers R (2019) Resisting corruption in Grameen Bank. J Bus Ethics 156(3):591-604

Bicchieri C, Duffy J (1997) Corruption cycles, in political corruption. Polit Stud XLV:477-495

Boakye KA (2010) Studying tourists' suitability as crime targets. Ann Tour Res 37(2):727-743

Brock W, Durlauf SD (2001) Growth empirics and reality. World Bank Econ Rev 15:229-272

Campos JE, Pradhan S (2007) The many faces of corruption: tracking vulnerabilities at the sector level, Washington, DC: World Bank. https://openknowledge.worldbank.org/handle/10986/6848. Accessed 6 Jul 2020

Caner M, Hansen BE (2004) Instrumental variable estimation of a threshold model. Economet Theor 20(5):813-843

Chan FH, Frey B, Skali A, Torgler B (2019) Political entrenchment and GDP misreporting. CREMA working paper series 2019-02, Center for Research in Economics, Management and the Arts (CREMA)

Charron N (2011) Party system, electoral systems and constraints on corruption. Elect Stud 30(4):595-606

Chen Y, Ioannides YM (2020) International tourism and short-run growth, working paper, Tufts University

Chong A, Gradstein M (2007) Inequality and institutions. Rev Econ Stat 89(3):454-465

Das J, DiRienzo C (2010) Tourism competitiveness and corruption: a cross-country analysis. Tour Econ 16(3):477-492

De Vita G (2014) The long-run impact of exchange rate regimes on international tourism flows. Tour Manag 45:226-233

Demir E, Gozgor G (2017) What about relative corruption? The impact of the relative corruption on the inbound tourism to Turkey. Int J Tour 19:358-366

DiRienzo C, Das J (2015) Innovation and role of corruption and diversity: a cross-country study. Int J Cross Cultur Manag 15(1):51-72

Draper D (1995) Assessment and propagation of model uncertainty. J R Stat Soc Ser B 57:45-97

Durlauf S, Kourtellos A, Tan CM (2008) Are any growth theories robust. Econ J 118(527):329-346

Ekine S (2018) Corruption and tourism: evidence from democracies and non-democracies. Issues Polit Econ 27(1):47-59

Feridun M (2011) Impact of terrorism on tourism in turkey: empirical evidence from Turkey. Appl Econ 43(24):3349-3354

Garin-Munoz T, Amaral TP (2000) An econometric model for international tourism flows to Spain. Appl Econ Lett 7(8):525-529

Gastanaga VM, Nugent JB, Pashamova B (1998) Host country reforms and FDI inflows: how much difference do they make? World Dev 26(7):1299-1314

Habibi F, Rahim KA, Ramchandran S, Chin L (2009) Dynamic model for international tourism demand for Malaysia: panel data evidence. Int Res J Financ Econ 33(1):208-217

Hadri K (2000) Testing for stationarity in heterogeneous panel data. Economet J 3(2000):148-161

Hanafiah MHM, Harun MFM (2010) Tourism demand in Malaysia: a cross-sectional pool time-series analysis. Int J Trade Econ Financ 1(1):80-83

Hansen BE (1999) Threshold effects in non-dynamic panels: estimation, testing, and inference. J Economet 93(2):345-368

Hansen BE (2000) Sample splitting and threshold estimation. Econometrica 68(3):575-603

Hansen BE (2017) Regression kink with an unknown threshold. J Business Econ Stat 35:228-240

Harris LC (2012) Ripping off tourists: an empirical evaluation of tourists' perceptions and service worker (mis)behavior. Ann Tour Res 39(2):1070-1093

Hart E (2019) Guide to using corruption measurements and analysis tools for development programming. https://www.u4.no/publications/guide-to-using-corruption-measurements-and-analysis-toolsfor-development-programming. Accessed 6 Jul 2020

Hellman JS, Jones G, Kaufmann D (2000) Seize the State, seize the day: state capture, corruption, and influence in transition. The World Bank. Policy Research Working Paper. WPS 2444

Henderson JC (2003) The politics of tourism in Myanmar. Curr Issue Tour 6(2):97-118 
Hough D (2016) Here's this year's (flawed) corruption perception index. Those flaws are useful. https://www.washingtonpost.com/news/monkey-cage/wp/2016/01/27/how-do-you-measurecorruption-transparency-international-does-its-best-and-thats-useful. Accessed 6 Jul 2020

Huntington S (1968) Political order in changing societies. Yale University Press, New Haven

Ibrahim MAMA (2011) The determinants of international tourism demand for Egypt: panel data evidence. Eur J Econ Fin Admin 30:1450-2275

Im K, Pesaran MH, Shin Y (2003) Testing for unit roots in heterogeneous panels. J Economet 115:53-74

Imran SM, Rehman HU, Khan REA (2019) Determinants of corruption and its impact on firm performance: Global evidence. Pak J Commer Soc Sci 13(4):1017-1028

International Country Risk Guide PRS Group (2020) https://www.prsgroup.com/explore-our-products/ international-country-risk-guide/. Accessed 20 May 2020

Kass RE, Raftery AE (1995) Bayes factors. J Am Stat Assoc 90:773-795

Kaufmann D, Wei SJ (2000) Does 'grease money' speed up the wheels of commerce? (WP/00/64, IMF working paper https://www.imf.org/external/pubs/ft/wp/2000/wp0064.pdf. Accessed 22 Sept 2019

Kaufmann D, Pradhan S, Ryterman R (1998) New frontiers in diagnosing and combating corruption. PREM Notes, No. 7, October; 1-6. The World Bank

Kaufmann D, Kraay A (2002) Growth without governance. Economia 3(1):169-229

Kaufmann D, Vicente PC (2011) Legal corruption. Econ Politics 23(2):195-219

Khadaroo J, Seetanah B (2007) Transport infrastructure and tourism development. Ann Tour Res 34(4):1021-1032

Kourtellos A, Stengos T, Tan M (2016) Structural threshold regression. Economet Theor 32(4):827-860

Krambia-Kapardis M (2016) Corporate fraud and corruption: a holistic approach to preventing financial crises. Palgrave Macmillan, New York

Larsen S, Brun W, Øgaard T (2009) What tourists worry about-construction of a scale measuring tourist worries. Tour Manag 30(2):260-265

Lau TS, Hazari BR (2011) Corruption and tourism. In: Hazari BR, Hoshmand R (Eds) Tourism, trade and welfare: theoretical and empirical issues, (159-170). New York: Nova Publishers

Leamer EE (1978) Specification searches. Wiley, New York

Leitão NC (2010) Does trade help to explain tourism demand? The case of Portugal. Theor Appl Econ 3(544):63-74

Levin A, Lin C-F, Chu C-S (2002) Unit root tests in panel data: asymptotic and finite sample properties. J Economet 108:1-24

Lien DHD (1986) A note on competitive bribery games. Econ Lett 22:337-341

Lui FT (1985) An equilibrium queuing model of bribery. J Polit Econ 93(4):760-781

Lv Z, Xu T (2017) A panel data quantile regression analysis of the impact of corruption on tourism. Curr Issue Tour 20(6):603-616

Lyrio MVL, Lunkes RJ (2018) Thirty years of studies on transparency, accountability, and corruption in the public sector: the state of the art and opportunities for public research. Public Integr 20:512-533

Mauro P (1995) Corruption and growth. Q J Econ 110(3):681-712. https://doi.org/10.2307/2946696

Mauro P (2002) The persistence of corruption and slow economic growth. IMF working paper, WP/02/213

Meo MS, Chowdhury MAF, Shaikh GM, Ali M, Masood Sheikh S (2018) Asymmetric impact of oil prices, exchange rate, and inflation on tourism demand in Pakistan: new evidence from nonlinear ARDL. Asia Pacific J Tour Res 23(4):408-422

Méon PG, Sekkat K (2005) Does corruption grease or sand the wheels of growth? Public Choice 122(1):69-97

Naidu S, Chand A, Pandaram A (2017) Exploring the nexus between urbanisation, inflation and tourism output: empirical evidences from the Fiji Islands. Asia Pacific J Tour Res 22(10):1021-1037

Neumayer E (2004) The impact of political violence on tourism: dynamic cross-national estimation. J Conflict Resolut 48(2):259-281

Nonthapot S, Lean HH (2013) Demand of Thai tourists to Lao PDR: an ARDL approach. Asian J Emp Res 3(3):279-285

Papathanassis A (2016) Curing the 'beach disease': corruption and the potential of tourism led transformation for developing countries and transitional economies. Ovidius Univ Ann Ser Econ Sci 16(1):75-80

Polemis ML, Stengos T (2018) does competition prevent industrial pollution? Evidence from a panel threshold model. Bus Strateg Environ 28(1):98-110

Poprawe M (2015) A panel data analysis of the effect of corruption on tourism. Appl Econ 47(23):2399-2412 
Raftery A, Madigan D, Hoeting J (1997) Bayesian model averaging for linear regression models. J Am Stat Assoc 92:179-191

Saha S, Yap G (2015) Corruption and tourism: an empirical investigation in a nonlinear framework. Int J Tour Res 17(3):272-281

Salman AK (2003) Estimating tourist demand through cointegration analysis: Swedish data. Curr Issue Tour 6(4):323-339

Santana-Gallego M, RossellÃ-Nadal J, Fourie J (2016) The effects of terrorism, crime and corruption on tourism. Econ Res Southern Africa (ERSA) 595:1-28

Santos GEDO, Gursoy D, Ribeiro MA, Netto AP (2019) Impact of transparency and corruption on megaevent support. Event Manag 23:27-40

Schwindt-Bayer L, Tavits M (2016) Clarity of responsibility, accountability, and corruption. In: Clarity of responsibility, accountability, and corruption (p. Iii). Cambridge: Cambridge University Press

Seo MH, Shin Y (2016) Dynamic panels with threshold effect and endogeneity. J Economet 195:169-186

Shleifer A, Vishny RW (1993) Corruption. Q J Econ 108(3):599-617

Song H, Li G (2008) Tourism demand modelling and forecasting - a review of recent research. Tour Manag 29(2):203-220

Surugiu C, Leitão NC, Surugiu MR (2011) A panel data modelling of international tourism demand: evidences for Romania. Econ Res-Ekonomska Istraživanja 24(1):134-145

Swaleheen M (2011) Economic growth with endogenous corruption: an empirical study. Public Choice 146:23-41

Transparency International (2012) Corruption perceptions index 2012. Transparency International: Berlin. https://www.transparency.org/cpi2012/results. Accessed 13 Feb 2017

Transparency International (2017) Corruption perception index 2017. Transparency International: Berlin. https://www.transparency.org/en/news/corruption-perceptions-index-2017\#. Accessed 11 Jun 2020

Transparency International (2019) Corruption perception index 2019. Transparency International: Berlin. http://www.transparency.org/2019. Accessed 12 April 2020

UNWTO (2015) Compendium of tourism statistics by united nation world tourism organization. http:// www.e-unwto.org/loi/unwtotfb. Accessed 13 Feb 2017

UNWTO (2020) Impact assessment of the covid-19 outbreak on international tourism. Updated 27 March $2020 \mathrm{https}: / /$ www.unwto.org/impact-assessment-of-the-covid-19-outbreak-on-international-tourism. Accessed 3 May 2020

UNWTO (2020) Impact assessment of the COVID-19 outbreak on international tourism. Updated 24 March 2020. https://webunwto.s3.eu-west-1.amazonaws.com/s3fs-public/2020-03/2403Coronavirus.pdf. Accessed 42020

Wei SJ (1999) How taxing is corruption on international investors? Rev Econ Stat 81(4):1-12

World Bank (2020) World development indicators. World Bank. https://datacatalog.worldbank.org/dataset/ world-development-indicators. Accessed 15 May 2020

World Tourism Organisation (2015) 2015 Edition of UNWTO tourism highlights. http://www.e-unwto.org/ doi/pdf/https://doi.org/10.18111/9789284416899. Accessed 6 Jan 2017

World Tourism Organisation (2018) 2018 Edition of UNWTO tourism highlights. https://www.e-unwto. org/doi/pdf/https://doi.org/10.18111/9789284419876. Accessed 20 Jan 2019

World Tourism Organisation (2019) 2019 Edition of UNWTO tourism highlights. https://www.e-unwto. org/doi/pdf/https://doi.org/10.18111/9789284421152. Accessed 9 Jun 2020

World Tourism Organization (2020) Growth in international tourist arrivals continues to outpace the economy. World tourism barometer No. 18, all regions, 20th January. https://www.unwto.org/worldtourism-barometer-n18-january-2020. Accessed 5 May 2020

World Travel and Tourism Council (2018) Tourism as a driver of peace https://www.wttc.org/-/media/files/ reports/special-and-periodic-reports/tourism-as-a-driver-of-peace--report-summary-copyrighted.pdf. Accessed 9 May 2018

Yadav V (2012) Legislative institutions and corruption in developing country democracies. Comp Pol Stud 45(8):1027-1058

Yadav V, Mukherjee B (2016) The politics of corruption in dictatorships. Cambridge University Press, New York

Yap G, Saha S (2013) Do political instability, terrorism and corruption have deterring effects on tourism development even in the presence of UNESCO heritage? A cross-country panel estimate. Tour Anal 18(5):587-599 
Zhao JH, Kim SH, Du J (2003) The impact of corruption and transparency on foreign direct investment: an empirical analysis. MIR Manag Int Rev 43(1):41-62

Publisher's Note Springer Nature remains neutral with regard to jurisdictional claims in published maps and institutional affiliations. 